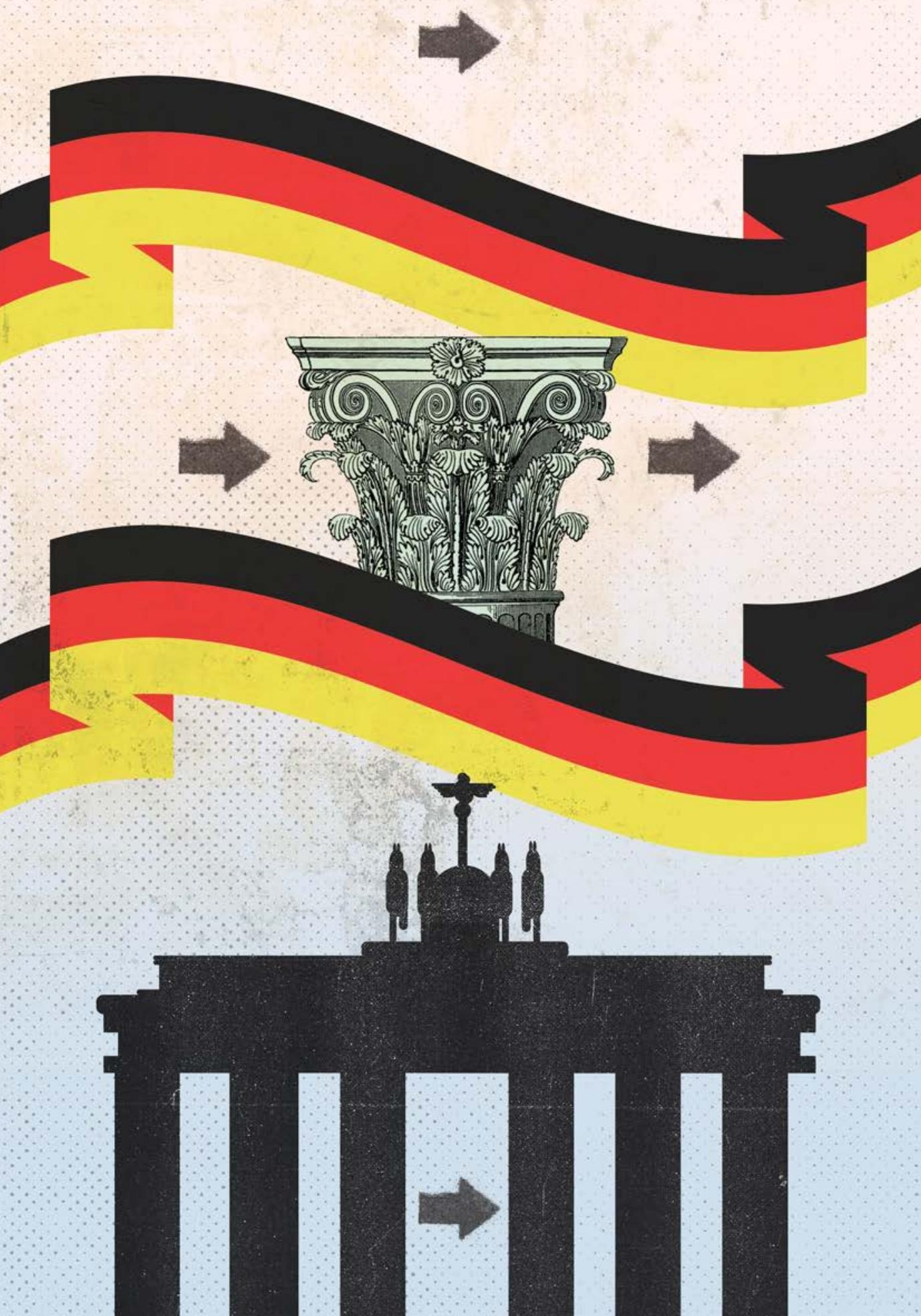




\title{
Between Opportunism and Limitation: the resurgence of populism and the right-wing populist 'Alternative for Germany' (AfD)
}

\author{
Entre Oportunismo e Limitação: o \\ ressurgimento do populismo e o populismo \\ de direita da 'Alternativa para a Alemanha' \\ (AfD)
}

\author{
* Veith Selk \\ ** Jared Sonnicksen
}

\begin{abstract}
The article provides first an overview of the strands of current research on populism and the German newcomer party, the Alternative für Deutschland (AfD). Building upon this, it will be demonstrated how the AfD constitutes a rightwing populist party, but also how its ideology connects to ideational-historical currents that have been influential in the Federal Republic of Germany. Finally, we elaborate the underlying thesis that the AfD comprises a party that is oriented primarily toward re-adjusting and resetting borders. Accordingly, the party manages to successfully politicize the cleavage between supporters of more openness and supporters of stronger delimitation.
\end{abstract}

Keywords: AfD, populism, right-wing populism, political conflict, borders.

\begin{abstract}
Resumo
O artigo fornece inicialmente uma visão geral das vertentes da pesquisa atual sobre o populismo eo novo partido alemão, a Alternativa para Alemanha (AfD). Com base nisso, será demonstrado como a AfD constitui um partido populista de direita, mas também como sua ideologia se conecta com correntes ideacional-históricas que foram influentes na República Federal da Alemanha. Finalmente, elaboramos a tese subjacente de que a AfD é composta por um partido que se orienta principalmente para o reajuste e restabelecimento das fronteiras. Consequentemente, o partido consegue politizar com êxito a clivagem entre partidários de mais abertura e partidários de uma delimitação mais forte.
\end{abstract}

Palavras-chave: AfD, Populismo, populismo de direita, conflito político e fronteiras.

\footnotetext{
* Dr. Veith Selk works as a research associate at the Institute of Political Science at the Technical University Darmstadt. His main areas of reasearch are Modern Political Theory and the History of Political Thought. Contact: selk@pg.tu-darmstadt.de

** Dr. Jared Sonnicksen works as a research associate at the Institute of Political Science at the Technical University Darmstadt. His main areas of research are comparative government and challenges of democracy under conditions of complex governance. Contact: sonnicksen@pg.tu-darmstadt.de
} 


\section{Introduction: the populist backdrop and the emergence of the AfD}

Political systems across Europe and the Americas have been facing a growing resurgence of populism. Elections in the last year alone - whether in the electoral primaries in the USA and the astonishing success of Donald Trump, the victory of the 'Brexit'-campaign in the United Kingdom, or the impressive results for the newcomer party Podemos in the Spanish national elections - exemplify not only the significance of the widespread populist wave in current politics. More fundamentally, they also attest to political developments that have actually been in the making for quite some time now. This may apply even more so with regard to right-wing populism, which has come to pose a veritable 'problem child' for research on parties and party systems in transition as much as on modern democracy in general. While the Left is meanwhile no stranger to populist movements (indicated for instance by the successes of Podemos in Spain, Syriza in Greece, Beppe Grillo and the Five Star Movement in Italy, or even Hugo Chavez in Venezuela), the proliferation of right-wing populist parties in particular and, coupled with this, of (re-)nationalistic, nativist and anti-immigration as well as anti-establishment, anti-globalist and anti-pluralist sentiments in numerous countries invite a host of concerns. Indeed, these trends have increasingly flamed debate in politics and society as much as in academia and especially political science. At the same time, populism continues to occupy an ambiguous place in multiple ways, as there is ultimately a profound lack of consensus on 'what to make of' populism (see e.g. Decker et al. 2015). In sum, the normative-analytical perspectives range from a 'danger for democracy' (see e.g. Müller 2016)) intensifying the erosion of political trust, liberal and plural values and stability on the one hand, to a'useful corrective' or even a'radical democratic articulation of the people' (see e.g. Laclau 2005), stimulating established parties and institutions to adapt to new or neglected citizen demands and identities on the other, as well as a host of nuanced and differentiated views in between (see e.g. Kaltwasser 2012). Yet, uncertainties are identifiable already on the rather descriptiveanalytical side as well. The determinants of populism, whether populism comprises a proper ideology or not, or what constitutes populism at all, not to mention the often difficult distinction toward other political ideational groupings (e.g. 'EU-sceptic', nationalist, regionalist and especially right-wing extremist groups and parties) have frequently been contested issues of definition and analysis. It is not least against this backdrop that the study of the emergence and development of the German Alternative für Deutschland ('Alternative for Germany', AfD) represents a complex endeavor.

For one, it is only of fairly recent, and with the AfD in particular, that rightwing populism has come to amount to a significant political force in the German party system. In most European countries, right-wing populism has been on the rise for many years. The list of countries with successful parties challenging the 'establishment' from the right has meanwhile expanded substantially within the last decade, many of 
which have even managed to gain not only sizeable shares of seats in parliaments, but even government office in several cases. These trends seem to have been intensified in the wake of the Euro- and financial crisis triggered in 2008/09 in the European Union. Germany on the other hand long appeared to make up a special case, not least since it had been literally surrounded by countries with more or less strong right-wing parties (e.g. the Front National in France, the Vlaams Blok (later Vlaams Belang) in Belgium, the Lijst Pim Fortuyn and then the Partij voor de Vrijheid in the Netherlands, the Schweizerische Volkspartei in Switzerland, the Freiheitliche Partei Österreichs in Austria, Fidesz and Jobbik in Hungary, Prawo i Sprawiedliwość in Poland, Forza Italia and Lega Nord in Italy or the Dansk Folkparti in Denmark, just to name a few). In Germany by contrast, the occasional successes of right-wing populist or nationalist parties at state (Länder) and local level (e.g. the Partei Rechtsstaatlicher Offensive in Hamburg, Die Republikaner in Baden-Wurttemberg, or the Nationaldemokratische Partei Deutschlands in a few eastern Länder) constituted more exceptions confirming this rule. Those electoral successes were mostly temporary and, for over five decades since the founding, consistently failed to materialize into the electoral support needed ( $5 \%$ of the vote) to gain entrance in the Bundestag, the federal parliament. Given these circumstances, Germany even had the appearance of an "Elysian field" in this regard (Decker 2003), where despite having comparable levels of attitudes and (re-) sentiments favorable to right-wing populism and extremism, perhaps the legacy of the National-Socialist past must have been so effective as to deter significant shares of voters from electing such parties.

As of current, there is a great deal of reason to expect that this will change with the next Bundestag election in the fall of 2017 due to the popularity of the AfD. Judging by national surveys so far, the party could receive between 10 and 15 percent of the vote and would thus be represented in the federal parliament. Moreover, the state and local elections would appear to underline the more sustainable success of the AfD, having garnered for instance in all Länder elections that took place in 2016 doubledigit shares of the vote (15\% in Baden-Wurttemberg; ca. 13\% in Rhineland-Palatinate; and $24 \%$ in Saxony-Anhalt, the second-largest percentage of the vote there; see e.g. Spiegel 2016). Given these political developments, in addition to the general public, politics and media, political scientists have been increasingly addressing the questions of how to explain the success of the AfD and what political significance it has.

Among party researchers, there was at first considerable dispute as to whether the Alternative for Germany party (AfD), founded in 2013, constituted a right-wing populist party at all (see e.g. Lewandowsky 2015). While this would appear trivial by now, the question was quite valid for a time since the AfD in its founding stage focused almost exclusively on ordo-liberal standpoints, to a large extent in critical reaction to Germany's leadership in the (unpopular) bailout policies during the Euro-crisis. ${ }^{1}$ The party also demonstrated a rather reserved, and explicitly serious political style, nearly without any xenophobic overtones in their campaign. Moreover, their image was 
dominated by a group of liberal economics professors who comprised the leadership level of the party. However, the AfD has shifted considerably, not only with regard to its party program, but also its personnel and political style increasingly toward rightwing populism (Häusler 2016; see also with a stronger focus on its electorate, Decker, Kiess und Brähler 2016). The debate on how to categorize the AfD may not be over, but it is at present being classified within party, right-wing extremism and populism research almost unanimously as right-wing populist (Bebnowski 2015, 2016; Ceyhan 2016; Decker 2016).

At the same time, it is important to note that there are a series of common issues and ideologies that demonstrate an affinity to right-wing populism. However, it does not coincide with a distinct set of political standpoints, a clearly definable ideological program or even a certain world view. Accordingly, analyses of the AfD have referred to different ideological-programmatic currents that can be identified within the AfD and that connect more or less with right-wing populism. They include foremost the ideologies of conservativism, nationalism and ordo-liberalism. In addition, there are thematic issues that have been discussed in AfD-related research as characteristic for the party, such as opposition to the Euro and deepened European integration, antiIslamism and rejection of a liberal immigration and asylum policy, antagonism toward gender mainstreaming efforts and other gender-policy reforms as well as critique of liberal family and societal policies.

Of particular interest and debate is likewise the question of the causes for the emergence and growth of right-wing populism and the AfD in particular. A large number of reasons have been asserted that may have favored or triggered the development of the AfD. These explanatory factors indicate a significant role of opportunity structures resulting on account of the transformation of the German party system. These changes include the increase in the formation of 'Grand Coalitions' (between the Christian Democratic Union (CDU) and the Social-democratic Party of Germany (SPD) as the traditional largest, 'catch-all' parties on the left and right side of the party spectrum respectively), the convergence in policies and party programs among the established parties, especially the liberalization of the CDU as well as the SPD's turn to the 'new middle' (akin to the British Labour Party's 'third way' reforms). Another factor is provided by the transition of the Free Democratic Party (FDP), the established liberal party, toward a focus on economic and financial liberalism, which it largely failed to translate into any significant such policy after returning to government in coalition with the CDU (2009-2013), thus during the apex of the Euro and financial crisis. Further opportunity structures affecting the party system in a manner conducive to new, challenger parties have been the series of crises or events perceived as crises in recent years (Euro- and financial crisis, the 'refugee' crisis, radical Islamism, etc.) as well as deeper societal processes of change (e.g. globalization, individualization, the coinciding uncertainty of traditional ways of living, medialization of politics, etc.). From social and political discourse, a growing perception of a fundamental crisis of political 
representation, reflected for instance in the concept of 'post democracy' (Crouch 2004), can even be concluded, which has likewise opened an effective window of opportunity for the AfD (as with other populist movements).

More specifically for the AfD, one significant factor may also be its organizational and personnel resources that the party had at its disposal from the outset. During its founding phase, the party surely benefitted from a large number of defecting political strategists, politicians, and party members from the established parties, most of all from the CDU but also the FDP, as well as support from right-wing networks such as the Zivile Koalition, to which Beatrix von Storch, a leading AfD-politician, belongs. In addition, a number of significant changes in the public discourse in Germany play into the overall opportunity framework favorable to the AfD, such as the notorious 'Sarrazin-Debate' (triggered by a widely read and controversially discussed book by Thilo Sarrazin 'predicting' how demographic developments, most of all due to immigrants, will lead to the downfall of Germany), post-democracy debates and the proliferating critique of political parties. More generally, several further trends in public discourse have surely played role such as an intensified antagonism toward 'political correctness' and seemingly growing support and popularity for'tell-it-like-it-is' political and societal figures. In addition, and for Germany of particular relevance, has been the gradual process of a 'relaxation' with regard to the Nazi past, along with a growing confidence and acceptance of national identity. Together, these factors have been assessed to serve as a sort of catalyzer for heightening the attractiveness of (as well as diminishing the long-held taboo against) right-wing populism in Germany (Decker 2015a; Nestler and Rohgalf 2014).

For party research, inquiry into the electoral structure of the AfD has likewise become relevant. For instance, key questions include who the AfD voters are and whether they extend beyond a group of protest voters or whether the AfD is gaining a more solid voter base and thus can establish itself accordingly in the German party system. That the latter applies is not improbable, as the majority of AfD voters demonstrate culturally conservative attitudes while also exhibiting an intense disaffection with the established parties. That implies that they are relatively homogenous with respect to two issues, cultural conservativism and critique of parties. Both features belong to the core of the AfD's program and make up perhaps its unique, if a defining feature (Schwarzbözl and Fatke 2016).

In parallel, academic research and discussion on the AfD needs to be viewed in context of current research on populism in general. In light of the rise of right-wing and, to a comparatively smaller extent, left-wing populism in Europe, research has grown commensurately on the phenomenon of populism and has worked intensely, among other things, on capturing it conceptually and theoretically. The conceptual discussion on the term and nature of populism has even been renewed of recent (Mudde 2004; Müller 2016; Priester 2012). However, it becomes evident that the term populism remains a contested concept, which provides a name to a significant phenomenon on 
the one hand and helps to conceptualize a number of current political tendencies. But it appears still to be strongly loaded with normative attitudes on part of the researchers on the other hand and is highly politically charged in the public as well as academic discussions. There is likewise dissent among researchers on the definitive traits of populism. Where there is consent though concerns the reference points of populism: it is characterized by a positive reference to 'the people' as a collective subject as well as a negative reference to 'the elite' and 'the establishment'. Yet there is analytical uncertainty or disagreement as to whether populism constitutes a political form (such as with a particular 'type' of party) in its own right or rather involves certain contents (such as issues) that typify various movements, parties and politicians as populist (see e.g. Puhle 2011). One common thesis postulates a certain form of identity politics as the distinguishing feature of populism, which thrives upon constructions of 'us against them' and obstructs the effective articulation and representation of concrete interests through grand narratives of identities that overarch interest differences (Steinert 1999). It is safe to presume that certain issues and ideologies are more prone or lend themselves more easily to this type of politicization than others, for instance issues like nation, cultural identity and religion.

Furthermore, research is confronted, perhaps as of recent more than ever, with the problematic relationship between populism and democracy and questions of which effects populist movements, parties and politicians have for the political culture of a democracy. Again, the guiding question can be summarized as one between'corrective' or rather'danger' to democracy. Cross-cutting this dualism though is another pertinent question of whether populism represents rather a purely symbolic 'simulation' of democratic empowerment of the people, whether useful or harmful. Depending on the particular diagnosis provided, the respective academic contributions differ considerably in their proposals for dealing with populism. They vary with regard to views on which types of reactions to the populist challenge in democracy may be acceptable, legitimate and effective (see e.g. Blühdorn 2016; Decker 2006; Jörke and Selk 2015; Münkler 2011). In addition to the approach to problem diagnosis, in many cases the political position and own democratic theoretical perspective of the researchers are reflected clearly in the different analyses. This is exemplified for instance in Chantal Mouffe's arguments for a left-wing populism, which she asserts would help revitalize democracy, politicize larger political debates and foster effective political mobilization against neo-liberalism (Mouffe 2016a, 2016b). Indeed, a great deal, and seemingly most, contributions to the discussion on populism presume explicitly or implicitly a certain ideal of democracy and arrive accordingly at different assessments of the phenomenon.

Questions on the causes and reasons behind the resurgence of populism in the USA, in Europe and in Latin America are raised in nearly all current research on populism. There has been particular focus also on why populism has experienced such a sizeable renaissance in Europe in the last decade, reflected in the increase of related 
parties and movements. As for the most recent years, the effects of the Euro-crisis in Europe came to the forefront of research interest as they have contributed to, among other things, the increased significance of populism (see e.g. Kriesi and Pappas 2015). Regarding Latin America and Asia, several scholars argue that a particular form of populism can be found there, which is admittedly characterized by an illiberal political program, but is less exclusive, in contrast to western and northern European rightwing populism, and rather much more oriented to inclusion. Such populism focuses namely on the inclusion of disadvantaged and marginalized minorities or societal groups (Mofitt 2015; Mudde and Rovira Kaltwasser 2013).

At the same time, current research on populism has brought forth an important, general finding that can prove insightful for understanding left-wing parties in western and northern Europe but also the success of Donald Trump in the United States. As illustrated above, right-wing populism in Europe has come to be characterized by a combination of what Frank Decker terms the "programmatic-thematic winning formula" of right-wing populism (Decker 2012: 22); i.e. right-wing populist parties resort increasingly to the welfare state in economic matters and take at the same time a conservative-nationalist position on cultural issues, while presenting themselves as critics of established parties and the political elite. As a result, they manage to appeal to a relatively large group of voters that may be referred to as 'dissatisfied left-conservatives.' Characteristic of this group is that they are dissatisfied with how the political system performs, prefer economically a leftist policy friendly to state intervention and redistribution, but hold conservative to reactionary values on the cultural and socio-political dimension (Lefkofridi, Wagner and Willmann 2014). Sociostructurally, this group tends to belong to the lower middle income class and lower strata of society, e.g. laborers, lower-level employees and the small-scale business selfemployed. Put simply, this suggests that right-wing populist parties tend to develop into parties of the 'little people', and that their claims to bring 'the people back in' can ring with large sections of society, not least in times of uncertainty. Along these line, a common thesis in research refers to the 'losers of globalization' (see e.g. Spier 2010), which encompasses not only socio-economic losses due to heightened competition, outsourcing and similar, but also perceived cultural losses through the coinciding transition of society. In turn, this assortment of findings bears no less relevance to understanding the popularity and position of the AfD in the German party system.

\section{Theses and analytical approach}

While the previous review of the research state of the art is far from exhaustive, it does provide an overview of the main strands of current research on populism. The following builds upon first research on the AfD. The meanwhile conventional classification of the AfD as right-wing populist will not be disputed, but we develop theses that go beyond the usual characterization of this party. As mentioned above, 
especially after its initial phase, the AfD has been depicted in the academic discussion for the most part as a party that combines right-wing populist strategies of mobilization with nationalistic, conservative and even reactionary to right-wing extremist as well as neo-liberal standpoints. This descriptive analysis is by no means incorrect, especially with a view to the personnel and the programmatic orientation of the party, but it misses the political significance of the AfD. As will be argued in the following, the party should be construed as a party of limitation. The theme of limitation - which can refer e.g. to borders, boundaries, restriction - provides the AfD with a unique feature, which connects to the emergence of a new (or renewed) societal cleavage that is being polarized by the AfD. In light of its electorate and party program, the AfD cannot qualify at present as a right-wing party of the lesser privileged. ${ }^{2}$

Thus, after revising the terms of populism and right-wing populism, it should become clear that the AfD is aptly characterized as right-wing populist in related party research. However, the ideational-historical basis and references of the AfD tend to be widely overlooked so far. When taking them into consideration, it becomes possible to locate the AfD more comprehensively in the ideational political history of Germany's federal republic. As will be argued, it represents less a 'foreign body' in the political system, but rather connects to political-ideological traditions and frames of reference that were long present and continue to be so. The opposite impression, namely that its party program and political orientation lack tradition in the Federal Republic of Germany, is only possible on account of the changes to the political culture and party system of the past two decades that have opened up a political'space'for a new party to occupy. Looking more closely at ideational historical currents of the past that were even influential in the German Federal Republic can reveal how to locate the AfD in a more continuous line of political-ideological thinking. In the final section then, the thesis will be elaborated on how the AfD, programmatically and thematically, resorts above all to the readjustment and re-drawing of borders and limits and thus distinguishes itself from the established parties in the political system. Why their positioning is successful electorally becomes comprehensible when considering the socio-cultural transformation of Germany and the coinciding emergence of a new political cleavage: a cleavage running between supporters of 'limitation' and supporters of 'opening'.

\section{Party program and political standpoints of the AfD}

In politicizing these issues, the AfD resorts often to a narrative that is typical for right-wing populism. Without repeating in depth the public rhetoric of AfD party leaders or the campaigns and public statements of prominent party members, media reporting on the party or the parliamentary work of the AfD-party groups in Länder parliaments (see e.g. Bebnowski 2015; Decker 2015b), the political significance of the party's critique of the political elite in the party program needs to be illustrated. A further reference point of critique of central importance to the party in this context 
concerns its depiction of threat to the collective identity of the German people. The program of the AfD commences with a sharp criticism of the conditions of the German political system. This involves foremost critique of the performance of representative democracy and the political parties in the Federal Republic.

Hence, a characteristic topos of populism becomes immediately salient, namely the corrupt political elite. The charge by the AfD is that the Federal Republic of Germany has disempowered the people while political power has been monopolized by the elite. They claim the existence of a 'political class of professional politicians' whose main concerns amount to interests in maintaining power, their status and material wellbeing, developing into nothing less than a "political cartel" that obstructs the people from having part in political decision making (AfD 2016: 8). Based on this diagnosis, the AfD deny the legitimacy of the representatives of the German people. Accordingly, the party claims in its program that the representatives in parliaments have forfeited their "mandates of the citizens". Furthermore, the political elites, who are identified in the program above all as the heads of parties, have rendered the state its prey; the veritable "omnipotence" of the parties and the "exploitation of the state" "threaten our democracy" (AfD 2016: 11). By combining the topos of corruption with critique of parties, the AfD taps into not only a common theme of right-wing populism, but also even longer-standing neo-republican notions of critique of corruption and the violation of popular will (see e.g. Sparling 2016).

The program section on "Culture, Language and Identity" is also quite revealing, again not least since affinities or analogies to right-wing populism can be identified especially with regard to these issues. Here the AfD refers to Germany as one of the "great European cultural nations" whose identity is primarily'determined by culture'(AfD 2016: 46). They demand moreover a "German mainline culture" (Leitkultur), insinuating a guiding cultural framework or a 'canon' of norms, values and behaviors that all must adhere to. To this end, they call for cultural political measures to strengthen this mainline culture, which they also justify as necessary steps to counteracting threats to German culture and thus German identity. These threats abound, especially due to the political elites and the "ideology of multiculturalism" they propagate, which puts not only national identity at risk, but also disturbs the public peace. According to the AfD program, the elites and their undermining of German culture pose a "serious threat to social peace and the persistence of the nation as a cultural unit" (AfD 2016: 47). Moreover, a threat to domestic security stems from the very presence and especially expansion of Muslim immigrants, who bear for the AfD "a great danger for our state, our society and our system of values" (AfD 2016: 49).

Indeed, this short series of excerpts from the party program alone clearly indicate the preponderance of right-wing typical political thinking, which is not difficult to detect or infer, but rather can be found directly in its official party program. On account of their political standpoints and, moreover, their success, the German party system may move closer to its European neighbors, where right-wing parties have meanwhile 
established themselves as a durable part of party competition. In turn, with the AfD, the once commonly held notion of Germany as political system and political culture that ensures the failure of right-wing populist and extremist parties is no longer tenable. However, when taking a closer look at ideational-historical development, the lack of a successful right-wing party for decades may obscure more than reveal about actual partisan dynamics and right-wing populist thinking there.

\section{The AfD and the ideational-historical context}

As already suggested above, the ideology of the AfD can be located in the history of political thought in the Federal Republic of Germany. While many commentators and especially political opponents have meanwhile referred to the AfD as an unprecedented political group and even a foreign body in the political culture of Germany, this line of argumentation is misleading, at least with regard to the programmatic-ideological standpoints of the party.

For instance, the party's program places a markedly strong emphasis on direct democracy. They call for the introduction of referendums at federal level and praise the Swiss system of direct democracy as a remedy to the problems of representative democracy and the dominance of parties in the political system. However, the party fails to provide a deep conceptual basis for their demands for more direct democracy, nor are there any specific, differentiated institutional proposals for implementing their demands. While concepts of direct democracy usually demonstrate some grounding in democratic theories or concepts (Rousseau, participatory democracy, socialist or communist council theories), the AfD program remains rather agnostic in this regard. Instead, the AfD would appear to demonstrate more of a'democracy pathos' or popular emotionalism, as illustrated in its critique of the European Union or its public election campaigns in general. The guiding political ideologies and theories for the party lie elsewhere.

Ideologically, the AfD has its roots in ordo-liberalism, Christian conservativism, (a particular strand of) statism and nationalism. Subsequently, the AfD is characterized by an orientation to the past, i.e. the party looks to the past for its proposals for solutions to societal problems, political ideals and goals. Moreover, a great deal of the ideological standpoints of the AfD can be matched with historical strands of political thinking that were not only at home in Germany, but, as with ordo-liberalism, were even developed there. Christian conservativism as well as nationalism and statism, much like ordo-liberalism, represent ideologies that have been influential in Germany's federal republic, especially in its early phase (Croner 1975; Dahrendorf 1965; Habermas 1980; Hoffmann 1996; Lenk 1989; Schäfer and Nedelmann 1967; Schmitz 2009).

Firstly, ordo-liberalism comprises a theoretical-ideological current that was founded by German political economists, sociologists and philosophers, in part still during the era of National Socialism, and which had a great deal of influence on the 
economic order after the founding of the German Federal Republic. The concept of Social Market Economy, which served as an immensely influential idea in designing the economic order, was developed by Alfred Müller-Armack, an important theoretician of the ordo-liberal school (see e.g. Müller-Armack 1966). Incidentally, the party program of the AfD makes explicit reference to the concept of social market and economy and the theory of ordo-liberalism, while virtually all of its economic policy demands can be attributed to ordo-liberal ideology (see e.g. AfD 2016: 66ff). This ideology makes up a specifically German variant of neo-liberalism. Like the latter, ordo-liberalism emphasizes market-economic "competition as process of discovery" (von Hayek 1969) and the rule-of-law and constitutional limitation of state power.

However, ordo-liberalism sees an inherent tendency in the market to destroy property and competition, especially as a result of the emergence and consolidation of cartels and oligopolies. Therefore, according to ordo-liberal theory, the state must take on the task of protecting the institutions of market-economic capitalism from their own self-destruction. Accordingly, state intervention into the market is permissible and necessary when it serves competition and does not disturb the connection between economic activity and economic risk and liability. In addition, ordo-liberalism prescribes socio-political measures of redistribution in order to prevent material poverty, but also to serve the realization of desirable goals which the market alone cannot fulfill. Thus, the scale of socio-political redistribution deemed justifiable and necessary by ordo-liberalism extends well beyond the degree usually conceded by neo-liberalism. Furthermore, ordo-liberalism is bound to a much stronger degree with a conservative ideal of society.

Again, the economic policy standpoints of the AfD comply substantially with this ideological strand. But, the party program AfD does exhibit two notions that stem less from ordo-liberalism, but rather from the political liberalism in the tradition of John Locke: namely the concepts of rule of law and separation of powers. In its program, the AfD calls for a restoration of separation of powers as they view the separation of powers in their current form in the political system of Germany as only partially maintained or safeguarded. This deficiency stems from, among other things, especially the blending of executive and legislative functions (although, incidentally, a more diffused and less strict delineation of executive and legislative actors is fundamentally characteristic of modern parliamentary democracy). Moreover, their demand builds upon the idea of a stricter legal restriction upon the executive to the formal equality of the citizens of the state.

Secondly, the AfD bases its ideology on Christian conservativism. Christianity takes the place of an essential part of the German mainline culture for the AfD. The dimension of Christian conservativism though is reflected particularly in its fairly skeptical view of humankind exhibited in the party program, which rejects reform projects of societal engineering and the 'improvement of humans' and postulates marriage and family as the'germ of civil society' (AfD 2016:40; though it is interesting to note the German word 
bürgerlich used in the original text can mean 'civil', but also'bourgeois'). The foundation of this ideology is the family-oriented subsidiarity principle, which prescribes the state to remain outside of the sphere of child raising and to respect the authority of parents over their children, particularly with regard to their goals for socialization and upbringing. This coincides with the notion of a 'natural' division of labor among the sexes by which both the man and woman are primary figures for children, but the woman in particular bears a crucial role during the early years of childhood. Thus, an ideal family consists of a heterosexual marriage between man and woman in which domestic child raising is the main responsibility of the woman while the man pursues a profession. However, these anti-egalitarian standpoints are somewhat contradicted by the AfD by their declared commitment to equal rights among the sexes. Still, they view the main task of the welfare state above all in promoting the upbringing of children by women through adequate socio-political measures. Another significant standpoint grounded in Christian conservativism is the idea of 'protecting the life' of embryos. While the AfD does not explicitly call for prohibiting abortion, they are open with their disapproval of it and propose instead a "culture of welcoming the new- and unborn" (AfD 2016: 44).

Thirdly, the AfD program has reference to the ideology of statism. This line of political thought envisions state sovereignty as endowed with the primacy of politics. Security and order comprise the highest goals of the state, with state interest taking precedent over the basic rights of citizens when necessary and allowing for repressive measures to resolve societal problems. In Germany, this ideology had influence especially through its connection to thought on the rule of law, which evolved out of the peculiar history of nation-state building in Germany. In contrast to founding legacies for instance in the French Republic or the United States of America, state unification in Germany in the late $19^{\text {th }}$ century did not institutionalize the linkage between law and liberty, but rather gave priority to 'unity' and 'law' over 'liberty'. In addition to 'hard on crime' demands for strengthening the police and justice system with more legal and personnel resources, the connection of the AfD to this ideology becomes most apparent in its diagnosis of societal problems. In the party program and a number of its campaign statements, the AfD laments the intensified decline of domestic security in Germany. In the program, a primacy of repressive security policy is illustrated in its demand for a 'security policy liberation' that makes 'protection of citizens' a priority again, which 'other matters must be subordinated to' (AfD 2016: 24).

Fourthly, the AfD ideology exhibits several features of ideological nationalism. At the center of this ideology is the view that a political community is not constituted and integrated by common political and legal principles alone, but rather by national, cultural or ethnic bonds of the citizens. Of course this ideology has been utmost influential in German history. Cultural nationalism in particular comprises a pivotal dimension of the AfD party program and positions. According to the party, the bonds of citizens do not derive from a common ethnic lineage as with ethno-nationalism, 
but rather a common language, a shared historical memory and experience as well as culturally grounds ways of life. The AfD summarizes these components into the phrase of a 'German mainline culture', which they attribute to Christianity, humanism and Roman law on the one hand, as well as the German language and history on the other. The 'German mainline culture' and German identity are depicted as seriously endangered by, above all, immigration to Germany, multiculturalism and its acceptance by the political elite, and the admission of asylum seekers to the Federal Republic.

Finally, an ideological-political constellation becomes identifiable, which does not adhere to one main current of political ideology, but, taken together, rather comprises several strands of ideological thinking. Nonetheless, the AfD can still clearly be categorized to the family of right-wing populists. Moreover, the exploration of these various ideological bases in an historical-ideational context reveals how the AfD poses much less a 'foreign' body to the political system of Germany, and rather builds upon and links to a number of political orientations that long had credence - and representation - in the German party system, not least the Christian conservative CDU or the (ordo-)liberal Free Democratic Party. A specificity or distinguishing feature, and perhaps 'novum', of the AfD, on the other hand, may constitute the combination of these basic ideological strands into a guiding theme of limitation.

\section{The AfD as a party of limitations}

Prior to the founding of the AfD, a number of researchers on party change and populism analyzed the development of a new, emerging cleavage in western European political systems. Among other factors, this development has coincided with transformation processes of the global era. For understanding right-wing populism and the $A f D$, the significance of this new cleavage is substantial, if not pivotal. The term cleavage refers to structurally embedded socio-cultural and economic differences. According to the original concept, i.e. constructed in particular view of party systems (Lipset/Rokkan 1967), they developed out of modernization and concomitant processes, such as secularization (church versus state), industrialization (capital versus labor) as well as urbanization (city/urban/industrial versus land/rural/agricultural) and, often coerced, centralization (center versus periphery). These lines of conflict, emerging out of socio-structural transformation, have served as wells of mobilization for the contrasting differences and reflected in corresponding parties (e.g. socialist parties on the labor side, liberal parties favoring secularism, Christian conservatives becoming politicized by the dislocation of church from state, farmers' parties reacting to their neglect under the predominance of industrial and business interests, regional parties forming against the overreach of the state center, etc.). Thus, parties - among other socio-political actors - contributed to politicizing the various conflicts of interest, ideology and identity, and tended to articulate and represent one pole of the cleavage (as with 'labor' versus 'capital', perhaps the most profound and enduring cleavage for 
modern party democracy). In turn, through co-decision in political institutions, these conflicts could likewise be pacified when parties managed to form compromises and accommodate variable interests.

While mass parties with cohesive ideological programs as well as solid electorates and large membership bases were characteristic for party systems well into secondhalf of the $20^{\text {th }}$ century, a transformation to catch-all parties set in on the one hand with looser ideological programs and less embedded in socio-structural groups of society. The significance of the cleavages for the identity of the parties declined in turn, as well as for citizens themselves, although these cleavages are still consequential for the societal structuring of political space (Kriesi 2007: 215ff.) According to Kriesi et al., a new cleavage has developed in line with the advanced processes of globalization and Europeanization, which have coincided with weakening nation-state sovereignty and engendering greater permeability to national societies for currents of communication, migration as well as goods, services and capital. The new cleavage revolves around supporters of more 'opening' and deepened political integration, and the supporters of 'closing' and delimitation, referred to as the "demarcation-integration conflict" (Kriesi et al. 2012). Correlating to the emergence of this new conflict in western democracies is a wider process of 'denationalization' (Zürn 1998). The process of advancing modernization since the epochal change in the world order since the fall of Soviet Empire has not of course led to the dissolution of nation-state borders. But they are being shifted across, above or beyond the state, in parts through supra- and transnationalization processes or through the construction and further integration of new political organizations and institutions.

These developments have not remained without their consequences for citizens in the states involved. On the one hand, more and more people enjoy a growing form of free mobility, for instance in work on the labor market or in leisure with tourism. They also benefit from a higher problem-solving capacity of denationalized political regimes. These changes have resulted on account of the limited capacity of nation-states that has become increasingly apparent in light of global and trans-national challenges and the intensified global interdependence. As such, intergovernmental, trans- and supranational regimes constitute a response to increased needs for cooperation and coordination to cope with growing interdependencies beyond the state.

Denationalization has provoked a host of consequences on the other hand that are perceived, if not experienced by large numbers of citizens as problematic. Through a transferal of representation and decision-making practices beyond the national context, denationalization leads to a weakening or overwhelming of those nationstate institutions, arenas and resources that are essential to democratic decision making, representation and accountability. This may apply above all to the national parliaments, parties, the broader public which is by and large bound in language and media to a national society, but also the horizons for making sense of and understanding politics and government on part of common citizens (Greven 2007; 
Möller 2015; Wilke 2014). Consequently, national political systems and societies face an increasing incongruence between those who are affected by political decisions and those who make them. A further implication is change in the nation-state societies, as waves of migration increase and the political culture of the affected states becomes likewise more and more denationalized; i.e. the citizenry in many cases (aside from more traditional 'immigration' and 'settler societies' like the USA, Canada or Australia) can no longer be described as an exclusive community bound by lineage, heritage and culture, but rather a multicultural society, whose citizens are bound to one another by their membership in a common political system.

In addition to processes of denationalization, changes to the political cultural have particular significance for the landscape of political contestation in Germany and affect the expansion of a 'demarcation-integration conflict'. On the whole, Germany's federal republic has experienced a socio-political shift toward more liberalization, among other things, in the course of the path-breaking participation in federal government (1998-2005) of the left-liberal, ecological party of the Greens and as a result of a societal, post-material value change. This may be observed in the growing acceptance of alternative identities and lifestyles, not least with regard to homosexuals, the acknowledgement of multiculturalism, as well as widespread demands in public discourse and numerous political actors for improved support for integration and a 'welcome culture' for refugees and asylum seekers. The changes are likewise reflected in revisions to legislation such as the law easing the process to becoming a citizen or in public gender equality and anti-discrimination measures. The changes in the realm of public opinions and citizen attitudes toward more liberality is likewise present or observable in the everyday lives of citizens, their increased acceptance of minorities and tolerance, but also a general depreciation for traditional, petite-bourgeois and working class lifestyles.

Consequently, the political system and culture in Germany has changed in a manner conducive to the emergence of the 'demarcation-integration conflict', which the AfD has managed to politicize effectively. Their election campaign strategies for one are geared toward (re)drawing borders and limits, illustrated by a number of campaign slogans and demands: to introduce a (much lower) limit on the number of eligible asylum seekers or to enhance the protection of the territory of the German state through a renewed border police (i.e. paramount to rescinding the Schengen Agreement in the EU which abrogated regular border controls among the signatory states). Furthermore, the party program and especially its orientation to the ideologies illustrated above can be construed together as an attempt to propagate symbolically and politically implement a renewed delimitation of the Federal Republic's political space.

In economic policies, the AfD demonstrates an analogous theme derived from ordo-liberal theory and political liberalism in its demand to redraw the lines between state functions in accordance with classic separation of powers and to reestablish 
the boundaries between economic activity and risk or liability. Accordingly, the AfD from the outset vehemently criticized the bailout programs responding to the Euro crisis. A guiding justification to their opposition referred to the fundamental problem of a state bailout, since this dissolves the connection between economic activity and entrepreneurial risk and induces a socialization of debts toward a common liability in the EU. Therefore, the party continues to call for a (re)limitation of common liability in the Eurozone.

Regarding the issues of migration and asylum, a focus on drawing and readjusting borders becomes especially salient with the AfD. It takes a stance of limiting citizenship to the Germany's 'majority society' committed to the 'German mainline culture'. This is linked with the demand to cease with admissions of refugees and immigrants. Concerning labor market immigration, the party proposes to limit migration on the basis of utilitarian criteria, i.e., based on domestic labor market needs for specialists and similar. At the same time, the AfD calls for dismantling the European Union to a large extent and returning competences to the national level, abolishing the common currency of the Euro as well as the Schengen system, i.e. a return to exclusively national boundaries of the political space.

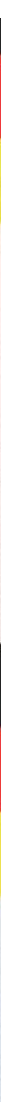


In cultural and identity politics, the political standpoints of the AfD correspond again clearly to the guiding idea of limitation. First of all is its symbolic delimitation of German identity strictly to all those who may count as German in the cultural national sense. Parallel to this is its rejection of 'constitutional patriotism' which is not based on a common culture, but rather recognition and affective relationship to the constitution as central feature of citizen identity. In addition, their endorsement of traditional gender identities and the heterosexual family goes hand in hand with their rejection of gender mainstreaming and sex education in schools promoting tolerance and acceptance of more diversity.

\section{Conclusion}

Parties and party systems face challenges of transformation across democratic countries, while the respective research in social and especially political science has grown commensurately. Among the numerous factors to explain the emergence, persistence as well as change in parties, the concept of cleavages has long provided a pivotal analytical frame. This applies no less to the rise of right-wing populism in Europe. While the classic cleavages (e.g. between center and periphery, between urban and rural, between church and state, and especially between capital and labor) have lost or diminished in structuring and mobilizing capacity for party politics, the concept nonetheless can be analytically informative, not least when allowing for the emergence of new or transformed cleavages. With regard to right-wing populism in Europa, Decker et al. for instance argue that party systems in democratic states are affected primarily by two basic cleavages, a 'socio-economic distributive' one and a 'socio-culture value conflict', whereas the new right-wing parties represent above all a phenomenon of the latter, i.e. value politics (Decker, Hennigsen and Jakobsen 2015: 15). Certainly, this proposition can apply to the AfD as well, though it requires qualification.

First, the two types of cleavage cannot always be clearly distinguished from one another. For instance, the issue of immigration policy, which is particularly significant for the AfD and its political mobilization, is on the one hand an expression of a sociocultural value conflict as immigration policy pertains to the issue of which groups of foreigners should have the opportunity to immigrate and based on which values should the right to membership in the community be allotted. On the other hand, immigration policy also has a socio-economic distributive dimension and is expression of socioeconomic conflicts as immigration policy is likewise a form of labor policy. It influences who may immigrate into the domestic labor market and who may not. Secondly, the current success of the AfD cannot be solely attributed to its cultural conservative values oriented to limitation and restriction. Equally, if not more responsible for the success of the party has been their ability to adopt the 'programmatic and electoral winning formula of European right-wing populists'. As phrased concisely by Decker 
et al., the right-wing populists benefit on economic-political issues from the 'fears of downward mobility' that affect ever larger parts of the middle classes in the course of 'accelerated modernization'; in the cultural dimension, they appeal to needs for a 'sense of belonging and identity' that many perceive as becoming lost in the'supposed value arbitrariness' of multiethnic societies; and politically, they raise the issue of a 'growing gap between the governors and the governed' (Decker, Hennigsen and Jakobsen 2015: 21), all of which, though along with other factors, have contributed to diminishing trust in conventional political institutions and even representative democracy.

In summary, the Alternative für Deutschland easily fits into this conceptualization of right-wing populism. However, one substantial difference is the economic position of the AfD in its party program. Aside from family policy, it actually strives for a considerable retrenchment of the welfare state, which incidentally would also affect the middle class severely. Thus, in light of their electorate, it would seem safe to expect that the AfD will shift economically toward the middle of the road in the near future. In doing so, they would only catch up with other right-wing populist parties in Europe that have already taken this path. 


\begin{abstract}
Notes
1 The party's name alludes to the critique of the policy of the German government, particularly Chancellor Angela Merkel, who during the high point of the Euro-crisis referred to the bailouts for troubled Euro-zone countries as 'without alternative' (alternativlos) for the survival of the EU. The core platform of the AfD involved currency reform, including concern for the southern European countries in the EU becoming crippled by the Euro, and a return to the German Mark, accompanied by a number of fiscal conservative policies such as debt reduction.

2 This is underlined by the circumstance that the number of dissatisfied 'left conservatives' in Germany is comparably low; see Lefkofridi, Wagner and Willmann 2014: 71.
\end{abstract}

\title{
References
}

ALTERNATIVE FÜR DEUTSCHLAND (2016). Programm für Deutschland. Das Grundsatzprogramm der Alternative für Deutschland, Beschlossen auf dem Bundesparteitag in Stuttgart am 30.04./01.05.2016.

BEBNOWSKI, DAVID (2015). Die Alternative für Deutschland. Aufstieg und gesellschaftliche Repräsentanz einer rechten populistischen Partei, Wiesbaden: Springer VS.

BEBNOWSKI, DAVID (2016). ,Gute“ Liberale gegen „böse“ Rechte? Zum

Wettbewerbspopulismus der AfD als Brücke zwischen Wirtschaftsliberalismus und

Rechtspopulismus und dem Umgang mit der Partei, in: Alexander Häusler (ed.), Die Alternative

für Deutschland. Programmatik, Entwicklung und politische Verortung, Wiesbaden: Springer VS, pp. 25-35.

BLÜHDORN, INGOFLUR (2016). Das postdemokratische Diskursquartett. Kommunikative Praxis in der simulativen Demokratie, in: Oliver Decker/Dennis Eversberg (eds.), Postwachstumsgesellschaft - Subjektivität - Demokratie. Psychosozial Schwerpunktthema 143, Gießen: Psychosozial Verlag,

pp. 13-31.

CEYHAN, SARA (2016). Konservativ oder doch schon rechtspopulistisch? Die politischen Positionen der AfD-Parlamentskandidaten im Parteienvergleich, in: Zeitschrift für Politikwissenschaft 26(1): 49-76.

CRONER, FRITZ (1975). Die deutsche Tradition, Opladen: Westdeutscher Verlag.

CROUCH, COLIN (2004). Post-Democracy, Cambridge: Polity Press.

DAHRENDORF, RALF (1965). Gesellschaft und Demokratie in Deutschland, München: Piper.

DECKER, FRANK (2003). Insel der Seligen? Warum deutsche Rechtspopulisten oft scheitern, in: Internationale Politik 4: 13-22.

DECKER, FRANK (ed.) (2006). Populismus. Gefahr für die Demokratie oder nützliches Korrektiv?, Wiesbaden:VS.

DECKER, FRANK (2012). Warum der parteiförmige Rechtspopulismus in Deutschland so erfolglos ist, in: Vorgänge 51(1):21-28.

DECKER, FRANK (2015a). AfD, Pegida und die Verschiebung der parteipolitischen Mitte, in: Aus Politik und Zeitgeschichte 65(40): 27-32.

DECKER, FRANK (2015b). Alternative für Deutschland und Pegida. Die Ankunft des neuen Rechtspopulismus in der Bundesrepublik, in: Frank Decker/Bernd Henningsen/Kjetil Jakobsen (eds.), Rechtspopulismus und Rechtsextremismus in Europa. Die Herausforderung der Zivilgesellschaft durch alte Ideologien und neue Medien, Baden-Baden: Nomos, pp. S. 75-90. 
DECKER, FRANK (2016). Die „Alternative für Deutschland“ aus der vergleichenden Sicht der Parteiforschung, in: Alexander Häusler (ed.), Die Alternative für Deutschland. Programmatik, Entwicklung und politische Verortung, Wiesbaden: Springer VS, pp. 7-23.

DECKER, FRANK/HENNIGSEN, BERND/JAKOBSEN, KJETIL (eds.) (2015). Rechtspopulismus und Rechtsextremismus in Europa. Die Herausforderung der Zivilgesellschaft durch alte Ideologien und neue Medien, Baden-Baden: Nomos.

DECKER, OLIVER/KIESS, JOHANNES/BRÄHLER, ELMAR (2016). Die enthemmte Mitte. Autoritäre und rechtsextreme Einstellungen in Deutschland, Gießen: Psychosozial Verlag.

DER SPIEGEL (2016). Abstimmungen in drei Ländern: Die Ergebnisse der Landtagswahlen im Überblick, in: Spiegel Online (14 March 2016), http://www.spiegel.de/politik/deutschland/ wahlen-2016-die-ergebnisse-der-landtagswahlen-im-ueberblick-a-1082093.html.

GREVEN, MICHAEL (2008). The Informalization of Transnational Governance: A Threat to Democratic Government, in: Edgar Grande/Lousi W. Pauly (eds.), Reconstituting Political Authority in the Twenty-first Century, Toronto: University of Toronto Press, pp. 261-284;

HABERMAS, JÜRGEN (ed.) (1980). Stichworte zur "geistigen Situation der Zeit". Vol. 1: Nation und Republik, Frankfurt am Main: Suhrkamp.

HÄUSLER, ALEXANDER (2016). Die AfD: Eine rechtspopulistische Partei im Wandel. Ein Zwischenbericht, DGB Diskurs (2/2016), Berlin: DGB.

HOFFMANN, JÜRGEN (1996). Politisches Handeln und gesellschaftliche Struktur. Grundzüge deutscher Gesellschaftsgeschichte, Münster: Westfälisches Dampfboot.

JÖRKE, DIRK/SELK, VEITH (2015). Der hilflose Antipopulismus, in: Leviathan 43(4): 484-500.

KALTWASSER, CRISTÓBAL ROVIRA (2012). The Ambivalence of Populism, in: Democratization 19(2): 184-208.

KRIESI, HANSPETER (2007). Vergleichende Politikwissenschaft. Teil 1: Grundlagen, Baden-Baden: Nomos.

KRIESI, HANSPETER ET AL. (2012). Political Conflict in Western Europe, Cambridge: Cambridge University Press.

KRIESI, HANSPETER/PAPPAS, TAKIS (2015). European Populism in the Shadow of the Great Recession, Colchester: ECPR Press.

LACLAU, ERNESTO (2005). On Populist Reason, London: Verso.

LEFKOFRIDI, ZOE/WAGNER, MARKUS/WILLMANN, JOHANNA (2014). Left-Authoritarians and Policy Representation in Western Europe: Electoral Choice across Ideological Dimensions, in: West European Politics 37(1): 65-90.

LENK, KURT (1989). Deutscher Konservatismus, Frankfurt am Main/New York: Campus.

LEWANDOWSKY, MARCEL (2015). Eine rechtspopulistische Protestpartei? Die AfD in der öffentlichen und politikwissenschaftlichen Debatte, in: Zeitschrift für Politikwissenschaft 25(1): 119-134.

LIPSET, SEYMOUR MARTIN/ROKKAN, STEIN (1967). Party Systems and Voter Alignments: Cross-national Perspectives, New York: Free Press.

MOFITT, BENJAMIN (2015). Contemporary Populism and the People in the Asia-Pacific Region: Thaksin Shinawatra and Pauline Hanson, in: Carlos de la Torre (ed.), The Promise and Perils of Populism: Global Perspectives, Kentucky: University Press of Kentucky, pp. 293-316.

MÖLLER, KOLJA (2015). Formwandel der Verfassung. Die postdemokratische Verfasstheit des Transnationalen, Bielefeld: Transcript Verlag. 
MOUFFE, CHANTAL (2016a). Für einen linken Populismus. Unsere Gegner sind nicht Migranten, sondern die politischen und ökonomischen Kräfte des Neoliberalismus, in: Internationale Politik und Gesellschaft, available at: http://www.ipg-journal.de/rubriken/soziale-demokratie/artikel/ fuer-einen-linken-populismus-857/.

MOUFFE, CHANTAL (2016b). Podemos: In the Name of the People, London: Lawrence and Wishar.

MUDDE, CAS (2004). The Populist Zeitgeist, in: Government and Opposition 39(4): 542-563.

MUDDE, CAS/ROVIRA KALTWASSER, CRISTÓBAL (2013). Exclusionary vs. Inclusionary Populism: Comparing Europe and Latin America, in: Government and Opposition 48(2): 147-174.

MÜLLER, JAN-WERNER (2016). Was ist Populismus?, Berlin: Suhrkamp.

MÜLLER-ARMACK, ALFRED (1966). Das gesellschaftspolitische Leitbild der Sozialen Marktwirtschaft, in: Alfred Müller-Armack (ed.), Wirtschaftsordnung und Wirtschaftspolitik, Freiburg im Breisgau: Rombach, pp. 293-315.

MÜNKLER, HERFRIED (2011). Populismus, Eliten und Demokratie: eine ideengeschichtlichpolitiktheoretische Erkundigung, in: Totalitarismus und Demokratie 8(2): 195-219.

NESTLER, CHRISTIAN/ROHGALF, JAN (2014). Eine deutsche Angst - Erfolgreiche Parteien rechts von der Union. Zur AfD und den gegenwärtigen Gelegenheitsstrukturen des Parteienwettbewerbs, in: Zeitschrift für Politik 61(4): 389-413.

PUHLE, HANS-JÜRGEN (2011). Populismus: Form oder Inhalt?, in: Henrique Ricardo Otten et al. (eds.), Kritik und Leidenschaft. Vom Umgang mit politischen Ideen, Bielefeld: Transcript, pp. 29-47.

PRIESTER, KARIN (2012). Wesensmerkmale des Populismus, in: Aus Politik und Zeitgeschichte 62(5-6): 3-9.

SCHÄFER, GERT/NEDELMANN, CARL (EDS.) (1967), Der CDU-Staat. Studien zur Verfassungswirklichkeit der Bundesrepublik, Munich: Szczesny Verlag.

SCHMITZ, SVEN-UWE (2009). Konservatismus, Wiesbaden: VS.

SPIER, TIM (2010). Modernisierungsverlierer? Die Wählerschaft rechtspopulistischer Parteien in Westeuropa, Wiesbaden: VS.

SCHWARZBÖZL, TOBIAS/FATKE, MATTHIAS (2016). Außer Protest nichts gewesen? Das politische Potenzial der AfD, in: Politische Vierteljahresschrift 57(2): 276-299.

SPARLING, ROBERT (2016). Corruption and Partisanship: Rousseau, Ferguson and Two Competing Models of Republican Revival, in: Canadian Journal of Political Science 49(1): 107-127.

STEINERT, HEINZ (1999). Kulturindustrielle Politik mit dem Großen \& Ganzen: Populismus, Politik-Darsteller, ihr Publikum und seine Mobilisierung, in: Internationale Gesellschaft und Politik 4(1999): 402-413.

VON HAYEK, FRIEDRICH AUGUST (1969). Der Wettbewerb als Entdeckungsverfahren, in: F. A. von Hayek (ed.) Freiburger Studien, Tübingen: Mohr Siebeck, pp. 249-265.

WILKE, HELMUT (2014). Demokratie in Zeiten der Konfusion, Berlin: Suhrkamp.

ZÜRN, MICHAEL (1998). Regieren jenseits des Nationalstaates. Globalisierung und Denationalisierung als Chance, Frankfurt am Main: Suhrkamp. 